\title{
Identification of mercury methylation product by tert-butyl compounds in aqueous solution under light irradiation
}

\author{
Baowei Chen ${ }^{\mathrm{a}, \mathrm{c}, *}$, Ping Chen ${ }^{\mathrm{b}}$, Bin $\mathrm{He}^{\mathrm{c}}$, Yongguang Yin ${ }^{\mathrm{c}}$, Linchuan Fang ${ }^{\mathrm{d}}$, Xiaowei Wang ${ }^{\mathrm{a}}$, Hongtao Liu ${ }^{\mathrm{b}}$, \\ Lihua Yang ${ }^{\mathrm{a}}$, Tiangang Luan $^{\mathrm{b}}$ \\ ${ }^{a}$ Guangdong Provincial Key Laboratory of Marine Resources and Coastal Engineering, School of Marine Sciences, Sun Yat-Sen University, Guangzhou 510275, PR China \\ ${ }^{\mathrm{b}}$ MOE Key Laboratory of Aquatic Product Safety, Instrumental Analysis E Research Center/School of Life Sciences, Sun Yat-Sen University, Guangzhou 510275, PR China \\ 'State Key Laboratory of Environmental Chemistry and Ecotoxicology, Research Center of Eco-Environmental Sciences, Chinese Academy of Sciences, P.O. Box 2871, \\ Beijing 100085, PR China \\ ${ }^{\mathrm{d}}$ State Key Laboratory of Soil Erosion and Dryland Farming on the Loess Plateau, Northwest AEF University, Yangling 712100, PR China
}

\section{A R T I C L E I N F O}

\section{Article history:}

Received 26 May 2015

Revised 13 June 2015

Accepted 5 July 2015

Available online 9 July 2015

\section{Keywords:}

Methylation

Monomethylmercury

Tert-butyl compounds

Ultraviolet irradiation

Aqueous solution

\begin{abstract}
A B S T R A C T
The methylation of mercury $(\mathrm{Hg})$ is of great concern as methylmercury $(\mathrm{MeHg})$, the most toxic species, is produced. This study examined the possibilities of tert-butyl compounds (tert-butyl alcohol (TBA) and tert-butyl hydroperoxide (TBH)) and other alcohols serving as methyl donors for $\mathrm{Hg}$ photo-methylation under light irradiation. The yield of MeHg varied among the methyl donors, and it was also significantly influenced by salinity and $\mathrm{pH}$. $\mathrm{MeHg}$ could be generated in the presence of TBH under visible light irradiation. The hydroxyl radical $(\cdot \mathrm{OH})$ was found to promote MeHg production at low levels, but degrade $\mathrm{MeHg}$ in excess. The photo-production of $\mathrm{MeHg}$ was tentatively proposed via the complexation of $\mathrm{Hg}$ and methyl donors, the formation of an intermediate $\left(\cdot \mathrm{O}(\mathrm{Hg}) \mathrm{C}\left(\mathrm{CH}_{3}\right)_{3}\right)$, and the intramolecular methyl transfer from methyl donors to $\mathrm{Hg}$. This study implicates photoreactions between $\mathrm{Hg}$ and organic pollutants in understanding the fate and transformation of $\mathrm{Hg}$ in the aquatic environment.
\end{abstract}

(c) 2015 Elsevier Ltd. All rights reserved.

\section{Introduction}

$\mathrm{Hg}$ pollution is of great concern because mercuric compounds can accumulate along the food chain with high toxicity to animals and humans (Crespo-Lopez et al., 2005; van Vliet et al., 2008; Zhang et al., 2010). Mercury can be detected in various environmental compartments, such as the atmosphere, water, sediments, and soils (Hall et al., 2009; Kieber et al., 2008; Muir et al., 2009; Obrist et al., 2011). Mercury is released into the environment mainly in its inorganic forms. However, the methylation of inorganic $\mathrm{Hg}$ is ubiquitous in the environment (Jonsson et al., 2012; Parks et al., 2013), which consequently leads to a significant increase in $\mathrm{Hg}$ toxicity. Methylmercury is considered to be one of the most toxic $\mathrm{Hg}$ species present in the environment (Darbieu, 1993; Grandjean, 2007), thus posing a great public health risk (Diez, 2009).

\footnotetext{
* Corresponding author at: Guangdong Provincial Key Laboratory of Marine Resources and Coastal Engineering, School of Marine Sciences, Sun Yat-Sen University, Guangzhou 510275, PR China.

E-mail address: chenbw5@mail.sysu.edu.cn (B. Chen).
}

Many efforts have been made to elucidate how MeHg is produced in the environment via biotic and/or abiotic pathways (Celo et al., 2006; Jensen and Jernelov, 1969). Microorganisms, such as sulfate-reducing bacteria and ion-reducing bacteria (Bridou et al., 2011; Fleming et al., 2006), are the major microbial contributors to $\mathrm{MeHg}$ production in the environment. However, the abiotic methylation of $\mathrm{Hg}$, which has been validated as an important pathway for $\mathrm{MeHg}$ production (Hammerschmidt et al., 2007), has not been studied thoroughly. Abiotic methylation of inorganic $\mathrm{Hg}$ by dissolved organic matter (DOM) under solar radiation is considered an important source of MeHg in lakes (Siciliano et al., 2005). Other methyl donors associated with $\mathrm{Hg}$ methylation in the environment, such as methylcobalamin, humic substances, methyltin compounds, and acetate, have also been reported (Cerrati et al., 1992; Chen et al., 2007a; Conaway et al., 2010; Weber et al., 1985).

Photoreactions play a key role in the transformation and biogeochemical cycling of elements in the environment (Guo et al., 2005; Hamilton et al., 2003; Moore, 2008). Elements (e.g., As, Se, and $\mathrm{Sn}$ ) are photochemically transformed in the presence of low-molecular-weight organic compounds (LMWOCs) (Chen et al., 2012; Guo et al., 2003; McSheehy et al., 2005). 
Photoreactions under solar or ultraviolet (UV) irradiation can contribute to both the production and degradation of $\mathrm{MeHg}$ in aquatic environments (Lehnherr and Louis, 2009; Li et al., 2010; Siciliano et al., 2005). In the presence of various LMWOCs, such as acetic acid, aldehydes, ketones, propionic acid, and ethanol, $\mathrm{Hg}$ photo-methylation was observed in aqueous solution under solar or UV irradiation (Yin et al., 2012). It is widely believed that the repertoire of methyl donors for $\mathrm{Hg}$ photo-methylation can be expanded continuously. Moreover, it is worth investigating the effects of other concurrent photoreactions on $\mathrm{Hg}$ methylation, for example, the photo-formation of reactive oxygen species (ROS).

Methyl tert-butyl ether (MTBE), in place of alkylated lead, has been used as a gasoline additive in the United States since the late 1970s. The level of MTBE in the environment is elevated due to accidental spill and leakage from underground tanks and transfer pipelines (Ayotte et al., 2008; Williams and Pierce, 2009). MTBE is highly hydrophilic; thus, it can readily dissolve in water and rapidly penetrate soils and aquifers. Consequently, MTBE and its major degradation product (tert-butyl alcohol, TBA) are often detected at the level of microgram per liter to milligram per liter in aquatic environments (Rosell et al., 2003; Schmidt et al., 2004). Furthermore, TBA, as a scavenger of $\mathrm{OH}$, can produce methyl groups for methylating elements in the presence of $\cdot \mathrm{OH}$ (Vonpiechowski et al., 1992). Therefore, TBA was selected as a methyl donor for inorganic $\mathrm{Hg}$ under UV irradiation.

The objectives of this study were to investigate the photo-methylation of $\mathrm{Hg}$ by TBA and tert-butyl hydroperoxide (TBH) in aqueous solution under the irradiation of UV or visible light, and to examine the influences of potential factors (salinity, $\mathrm{pH}$, methyl donors, and hydroxide radical) on the photo-methylation of $\mathrm{Hg}$. A tentative mechanism was proposed to elucidate the photo-generation of $\mathrm{MeHg}$ by tert-butyl compounds under UV irradiation.

\section{Materials and methods}

\subsection{Chemicals}

Monomethylmercury chloride and mercury chloride were purchased from Merck ( $\geqslant 98 \%$, Darmstadt, Germany). Stock solutions of monomethylmercury and inorganic mercury standards ( $1 \mathrm{mg} \mathrm{mL}^{-1}$ as $\mathrm{Hg}$ ) were prepared by dissolving appropriate amounts of methylmercury chloride in methanol and mercury chloride in $10 \%(\mathrm{v} / \mathrm{v})$ hydrochloric acid, respectively. Their working solutions were prepared daily by serial dilution in deionized water. Isopropyl alcohol (99.7\%) was purchased from Beijing Chemical Reagent (Beijing, China). TBA (99\%) and ethanol (100\%) were obtained from Phentex Corp. (USA). TBH (70\% aq.) was purchased from Alfa Aesar. All other chemicals were of analytical grade or higher. The mobile phase was prepared with deionized water obtained from a Barnstead ultrapure water system (Barnstead International, Dubuque, IA, USA).

\subsection{Photo-methylation reactions of $\mathrm{Hg}$ under UV irradiation}

The photo-methylation of $\mathrm{Hg}$ was conducted in a self-designed flow-through photoreactor equipped with a low-pressure Hg vapor UV lamp ( $254 \mathrm{~nm}, 11 \mathrm{~W}$, Beijing Research Institute for Light and Electric Instruments, Beijing, China) wrapped with a 4.5-m polytetrafluoroethylene (PTFE) tubing $(0.8 \mathrm{~mm}$ i.d. and $1.5 \mathrm{~mm}$ o.d., Kaisheng insulation material company, Shenzhen, China) (Yin et al., 2012). The reactor was enclosed in a sealed box for safety purposes. Photoreactions were conducted in a $10-\mathrm{mL}$ aqueous solution containing inorganic $\mathrm{Hg}\left(500 \mathrm{ng} \mathrm{mL}^{-1}\right.$ ) and methyl donors (200 mM for TBA, isopropyl alcohol and ethanol; $20 \mathrm{mM}$ for TBH).
The salinity and $\mathrm{pH}$ of the reaction solution were adjusted using sodium chloride $(5.0 \mathrm{M})$ and sodium hydroxide $(0.1 \mathrm{M})$, respectively. The reaction solution was passed through the reactor using a peristaltic pump (D100C, Huxi Instrumental Company, Shanghai, China). According to the flow rate, the reaction time was estimated to be approximately $6 \mathrm{~min}$. The effluent from the reactor was analyzed directly using high-performance liquid chromatography hyphenated with atomic fluorescence spectrometry (HPLC-AFS) or inductively coupled plasma mass spectrometry (HPLC-ICPMS) techniques.

\subsection{Photo-methylation reactions of $\mathrm{Hg}$ under visible light irradiation}

The photo-methylation reactions of $\mathrm{Hg}$ under visible light irradiation were also carried out in glass tubes filled with $10 \mathrm{~mL}$ of aqueous solution containing inorganic $\mathrm{Hg}\left(100 \mathrm{ng} \mathrm{mL}^{-1}\right)$ and methyl donors (TBA $(110 \mathrm{mM})$, ethanol $(180 \mathrm{mM})$, and TBH $(7.1 \mathrm{mM})$ ). The $\mathrm{pH}$ and salinity of the reaction solutions were not adjusted ( $\mathrm{pH}=7.1$ ). One group of reaction solutions were directly irradiated with natural sunlight in the laboratory, whereas the other group was placed in an incubator with a light intensity of $8000 \mu \mathrm{mol} \mathrm{m}^{-2} \mathrm{~s}^{-1}(390-700 \mathrm{~nm})$ at $25^{\circ} \mathrm{C}$ with a light/dark cycle of $14 \mathrm{~h} / 10 \mathrm{~h}$. After irradiation for 7 days, the reaction solutions were prepared using a MeHg extraction method reported in the literature (Yin et al., 2008), and these were subjected to HPLC-ICPMS analysis.

\subsection{Instruments and analytical methods}

$\mathrm{Hg}$ speciation analysis in the reaction solutions were carried out using the HPLC-AFS technique, as described in the literature (He et al., 2006). In brief, the HPLC system consisted of a quaternary pump (P680 HPLC Pump, Dionex, Sunnyvale, CA, USA), a Rheodyne model 7715i injector (Rheodyne, Cotati, CA, USA), and an Agilent Zorbax ODS column $(150 \times 4.6 \mathrm{~mm}, 5 \mu \mathrm{m})$. The mobile phase contained $5 \%(\mathrm{v} / \mathrm{v})$ methanol $\left(\mathrm{CH}_{3} \mathrm{OH}\right), 60 \mathrm{mM}$ ammonia acetate $\left(\mathrm{NH}_{4} \mathrm{Ac}\right)$, and $0.1 \%(\mathrm{v} / \mathrm{v})$ 2-mercaptoethnol $(\mathrm{pH} 6.8)$. The flow rate of the mobile phase was $0.4 \mathrm{~mL} \mathrm{~min}^{-1}$. A $20-\mu \mathrm{L}$ aliquot of the reaction solution was injected. $\mathrm{MeHg}$ in the effluent from the HPLC system was decomposed into inorganic $\mathrm{Hg}$ by $0.5 \%$ $\mathrm{K}_{2} \mathrm{~S}_{2} \mathrm{O}_{8}$ in $10 \%(\mathrm{v} / \mathrm{v}) \mathrm{HCl}$ under UV irradiation. After $0.5 \% \mathrm{KBH}_{4}$ was introduced into a $0.2 \% \mathrm{KOH}$ solution, cold vapor of $\mathrm{Hg}$ was generated and thereafter detected by an AF-610A nondispersive atomic fluorescence spectrometer (Beijing Rayleigh Analytical Instrument Co., China).

An HPLC-ICPMS technique was used to further confirm the presence of $\mathrm{MeHg}$ in the reaction solutions. Herein, $\mathrm{MeHg}$ and inorganic $\mathrm{Hg}$ were separated on an Agilent Zorbax XDB column $(50 \times 2.1 \mathrm{~mm}, 5 \mu \mathrm{m})$. The mobile phase is similar to that used for HPLC-AFS. The effluent from the analytic column was directly introduced into a 7500ce ICPMS instrument (Agilent Technologies, Santa Clara, CA, USA). The ICPMS was operated at a radiofrequency (RF) power of $1500 \mathrm{~W}$, a plasma gas flow rate of $15 \mathrm{~L} \mathrm{~min}^{-1}$, an auxiliary gas flow rate of $0.22 \mathrm{~L} \mathrm{~min}^{-1}$, a nebulizer gas flow rate of $0.82 \mathrm{~L} \mathrm{~min}^{-1}$, and a dwell time of $100 \mathrm{~ms}$. Mercury was monitored at $m / z 202$.

\subsection{Electron paramagnetic resonance spectrometry}

Following the photoreaction, the reaction solutions containing $1 \mu \mathrm{g} \mathrm{mL}^{-1}$ of $\mathrm{HgCl}_{2}$ (as $\mathrm{Hg}$ ), $1 \% \mathrm{NaCl}$ (w/v), $0.1 \mathrm{M}$ methyl donors, and $50 \mathrm{mM}$ of the spin-trapping agent 5,5-dimethyl-1-pyrroline $\mathrm{N}$-oxide (DMPO) were immediately analyzed using a Bruker E-500 electron paramagnetic resonance (EPR) spectrometer. The EPR spectrometer was operated at $9.774 \mathrm{GHz}$ using a cavity equipped with a Bruker Aquax liquid sample cell. The typical 
parameters of EPR were as follows: scanning range (100 G), field set $(3480 \mathrm{G})$, time constant $(40.96 \mathrm{~ms})$, scanning time $(83.89 \mathrm{~s})$, modulation amplitude $(1.0 \mathrm{G})$, modulation frequency $(100 \mathrm{kHz})$, receiver gain $\left(1.25 \times 10^{4}\right)$, and microwave power $(12.66 \mathrm{~mW})$.

\subsection{UV-visible spectrometry}

A Hitachi U-3310 spectrophotometer was used to determine the absorbance spectrum of reaction solutions. Three solutions containing methyl donors $(0.1 \mathrm{M}), \mathrm{HgCl}_{2}\left(100 \mathrm{ng} \mathrm{mL}^{-1}\right)$, or the mixture of methyl donor and $\mathrm{HgCl}_{2}$ were scanned. The scanning wavelength ranged from 190 to $700 \mathrm{~nm}$. The sampling interval was $1.0 \mathrm{~nm}$, and the slit width was set at $2 \mathrm{~nm}$.

\section{Results and discussion}

\subsection{Identification of $\mathrm{MeHg}$}

$\mathrm{MeHg}$ and inorganic $\mathrm{Hg}$ were separated well on an Agilent Zorbax ODS column, with the subsequent detection of $\mathrm{Hg}$ cold vapor using the AFS technique (He et al., 2006). Fig. 1 shows the typical HPLC-AFS chromatograms of $\mathrm{Hg}$ standards and the reaction solution (inorganic $\mathrm{Hg}$ and TBA). The retention times of $\mathrm{MeHg}$ and inorganic $\mathrm{Hg}$ were 17.1 and $20.3 \mathrm{~min}$, respectively. The detection of $\mathrm{MeHg}$ in the reaction solution indicated that inorganic $\mathrm{Hg}$ can be transformed into $\mathrm{MeHg}$, as well as other alcohols (e.g., isopropyl alcohol and ethanol), in the presence of TBA and TBH under UV irradiation. The HPLC-ICPMS technique was used to confirm the identity of the photo-methylation product of inorganic $\mathrm{Hg}$ under UV irradiation based on the mass-to-charge ratio of $\mathrm{Hg}$. The result also showed that $\mathrm{MeHg}$ can be produced via the photo-methylation of inorganic $\mathrm{Hg}$ by TBA and TBH under UV irradiation.

\subsection{The effects of different influencing factors}

The $\mathrm{pH}$ and salinity are widely considered to be important factors influencing element methylation in aqueous solution (Chen et al., 2006, 2007a,b, 2012; Yin et al., 2012). Therefore, the influences of salinity and $\mathrm{pH}$ on the photo-methylation of inorganic $\mathrm{Hg}$ were also investigated in the present study, and the results are shown in Fig. 2. Both $\mathrm{pH}$ and salinity exhibited significant effects on the production of $\mathrm{MeHg}$ in aqueous solution under UV irradiation. At a constant salinity of $0.2 \mathrm{M}$, the concentration of $\mathrm{MeHg}$ decreased with increasing $\mathrm{pH}$. The salinity used in this study ranged from 0 to $1.0 \mathrm{M}$, which covered all possible salinities

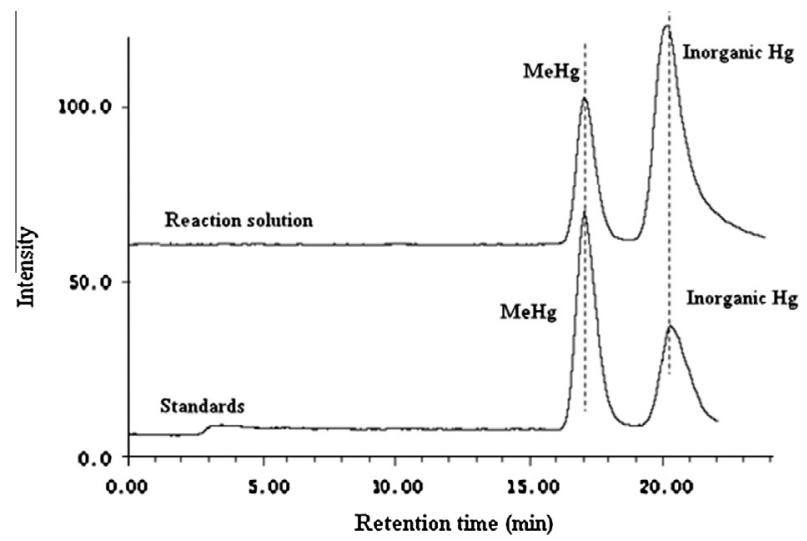

Fig. 1. HPLC-AFS chromatograms of $\mathrm{Hg}$ standards $\left(100 \mathrm{ng} \mathrm{mL}^{-1}\right)$ and $\mathrm{Hg}$ species in reaction solution. The reaction solution was obtained from the reaction between inorganic $\mathrm{Hg}\left(500 \mathrm{ng} \mathrm{mL}^{-1}\right)$ and TBA $(200 \mathrm{mM})$.
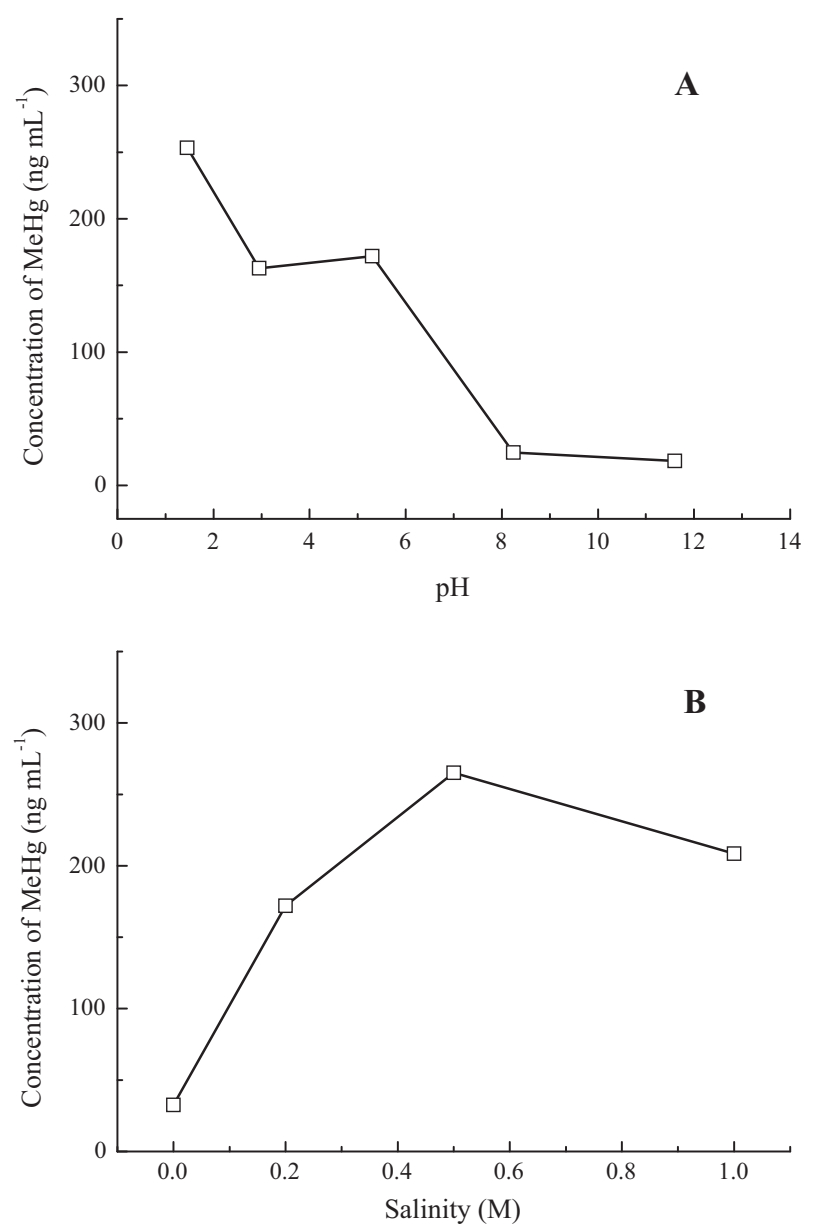

Fig. 2. Effects of $\mathrm{pH}(\mathrm{A})$ and salinity (B) on the photo-methylation of inorganic $\mathrm{Hg}$ by TBA in aqueous solution under UV irradiation.

observed in aquatic environments (e.g., about $0.5 \mathrm{M}$ for the seawater). The concentration of $\mathrm{MeHg}$ was highest at a salinity of $0.5 \mathrm{M}$ with a constant $\mathrm{pH}$ of 5.3. The equilibriums between free $\mathrm{Hg}^{2+}$ and its complexes with some anions (e.g., $\mathrm{OH}^{-}$and $\mathrm{C}^{-}$) as the functions of $\mathrm{pH}$ and salinity exist in the aqueous solution. The complexation of $\mathrm{Hg}^{2+}$ with anions reduces the availability of $\mathrm{Hg}$ for methyl donors (Chen et al., 2007a; Gardfeldt et al., 2003; Yin et al., 2012). Consequently, the production of $\mathrm{MeHg}$ decreased under the conditions of high $\mathrm{pH}$ and excess $\mathrm{Cl}^{-}$. However, the low level of $\mathrm{Cl}^{-}$promoted the production of $\mathrm{MeHg}$ in the aqueous solution, which probably resulted from the formation of $\mathrm{Cl}_{2}^{-}$facilitating the photolysis of LMWOCs under UV irradiation (Liu et al., 2009). Our results implied that the photo-methylation rate of inorganic $\mathrm{Hg}$ changed considerably among various hydrospheres due to great differences in their $\mathrm{pH}$ and salinity.

TBA can serve as a scavenger of the hydroxyl radical $(\cdot \mathrm{OH})$ (Vonpiechowski et al., 1992), and thus it is degraded by ${ }^{\circ} \mathrm{OH}$ via an intermediate of the alkoxyl radical $\left(\cdot \mathrm{OC}\left(\mathrm{CH}_{3}\right)_{3}\right)$ (Cederbaum et al., 1983a). The generation of hydroxyl radical ('OH) could substantially affect the photo-methylation of inorganic $\mathrm{Hg}$ by TBA in the aqueous solution. Fig. 3 demonstrates that the addition of hydrogen peroxide $\left(\mathrm{H}_{2} \mathrm{O}_{2}\right)$ initially increased the production of MeHg; thereafter, excess $\mathrm{H}_{2} \mathrm{O}_{2}$ over TBA drastically reduced $\mathrm{MeHg}$ production. The interaction between TBA and ${ }^{\circ} \mathrm{OH}$ can initially facilitate the formation of alkoxyl radical $\left(\cdot \mathrm{OC}\left(\mathrm{CH}_{3}\right)_{3}\right)$, which is beneficial to $\mathrm{MeHg}$ production. This may imply that the methylation of $\mathrm{Hg}$ by LMWOCs can be promoted by a certain level of $\cdot \mathrm{OH}$ even without UV irradiation, such as Fenton reactions, 


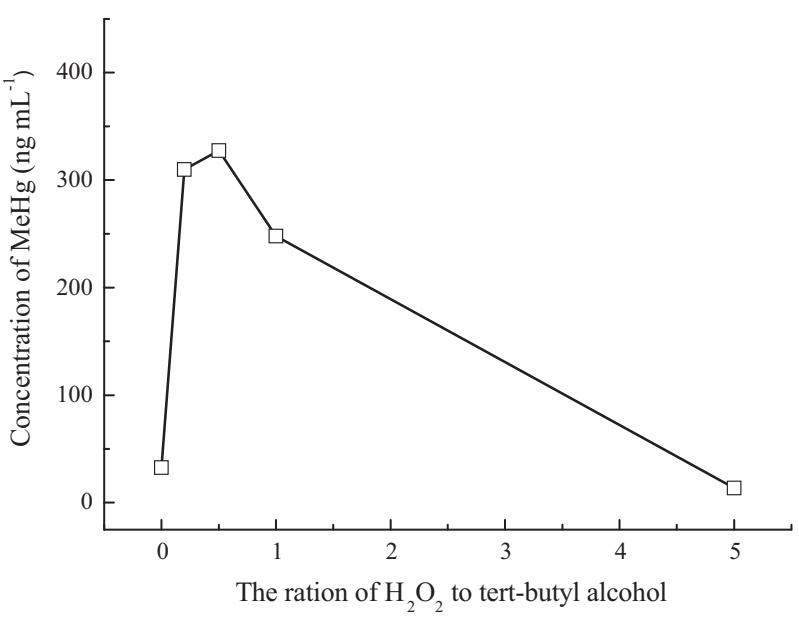

Fig. 3. Effect of hydrogen peroxide on the photo-methylation of inorganic $\mathrm{Hg}$ by TBA in aqueous solution under UV irradiation.

iron-catalyzed oxidation of ascorbic acid, or an enzymatic system, for example, the coupled oxidation of xanthine by xanthine oxidase (Cederbaum et al., 1983b; Hwang et al., 2010; Li et al., 2012). However, as the molar ratio of $\mathrm{H}_{2} \mathrm{O}_{2}$ to TBA was higher than 0.5 , the generation of excess $\mathrm{OH}$ under UV irradiation caused the degradation of MeHg (Chen et al., 2003; Lehnherr and Louis, 2009).

\subsection{Yield of $\mathrm{MeHg}$ by various methyl donors}

Several other small molecular organic compounds, including isopropyl alcohol, ethanol, and TBH, were also investigated as possible methyl donors under UV irradiation. The concentration and yield of $\mathrm{MeHg}$ are tabulated in Table 1. The yield of MeHg varied greatly for different methyl donors. The MeHg yield increased with the amount of methyl groups of the alcohols. Under the same reaction condition, TBA could produce over eight times more $\mathrm{MeHg}$ than isopropyl alcohol or ethanol could. In comparison with alcohols, the yield of MeHg was highest in the presence of TBH among all investigated organic compounds in this study, although the initial concentration of $\mathrm{TBH}$ was 10 times lower than other compounds.

Inorganic $\mathrm{Hg}$ was also photo-methylated by the methyl donors mentioned previously irradiation of visible light or sunlight. The result demonstrated that $\mathrm{MeHg}$ could only be detected in the presence of TBH under the irradiation of visible light or sunlight (Fig. 4), with significantly lower initial concentrations of both inorganic $\mathrm{Hg}$ (100 $\mathrm{ng} \mathrm{mL}^{-1}$ ) and TBH (7.1 mM) than under UV irradiation. MeHg accounted for approximately $0.05 \%$ of total $\mathrm{Hg}$ in the reaction solution.

Table 1

$\mathrm{MeHg}$ yield from photo-methylation of inorganic $\mathrm{Hg}$ by different methyl donors under UV irradiation ${ }^{\mathrm{a}}$.

\begin{tabular}{lll}
\hline $\begin{array}{l}\text { Methyl donors } \\
\text { (initial concentration) }\end{array}$ & $\begin{array}{l}\text { Concentration of MeHg } \\
\left(\mathrm{ng} \mathrm{mL} \mathrm{mL}^{-1}\right)\end{array}$ & $\begin{array}{l}\text { Yield } \\
(\%)\end{array}$ \\
\hline TBH $\left(20 \mathrm{mmol} \mathrm{L}^{-1}\right)$ & 452 & 90.4 \\
$\mathrm{TBA}\left(200 \mathrm{mmol} \mathrm{L}^{-1}\right)$ & 173 & 34.5 \\
Isopropyl alcohol $\left(200 \mathrm{mmol} \mathrm{L}^{-1}\right)$ & 21.2 & 4.3 \\
Ethanol $\left(200 \mathrm{mmol} \mathrm{L}^{-1}\right)$ & 17.6 & 3.5 \\
\hline
\end{tabular}

a Reaction conditions were as follows: a salinity of $0.2 \mathrm{~mol} \mathrm{~L}^{-1}$, a pH of 5.3, and an initial concentration of inorganic $\mathrm{Hg}$ of $500 \mathrm{ng} \mathrm{mL}^{-1}$.

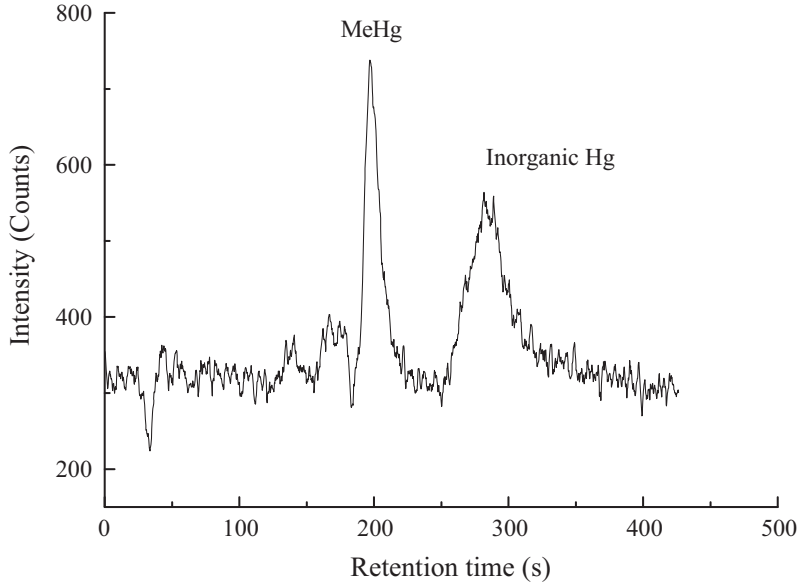

Fig. 4. HPLC-ICPMS chromatogram of $\mathrm{Hg}$ species in reaction solution of inorganic $\mathrm{Hg}$ and $\mathrm{TBH}$ under visible light irradiation.

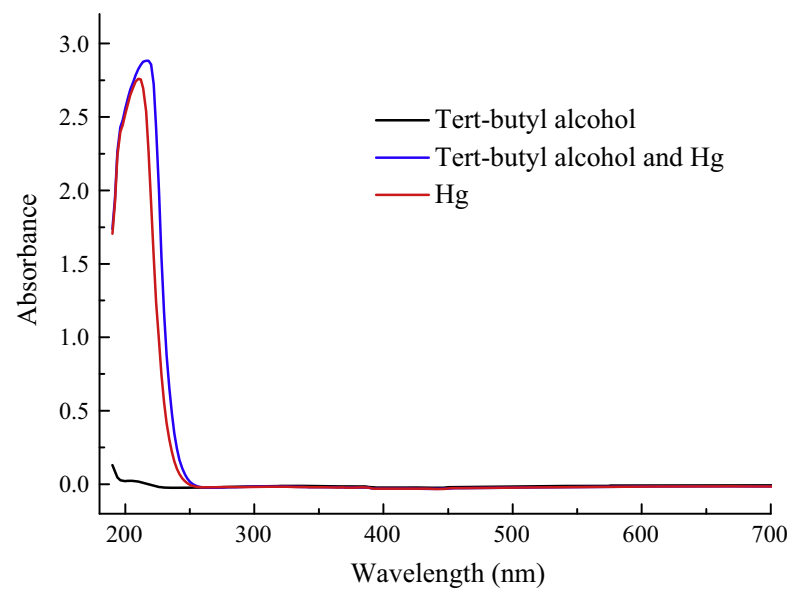

Fig. 5. UV-visible absorbance spectrum of TBA. The final concentrations of TBA and $\mathrm{TBH}$ were $0.1 \mathrm{M}$, and the concentration of $\mathrm{HgCl}_{2}$ was $100 \mathrm{ng} \mathrm{mL}^{-1}$ as $\mathrm{Hg}$.

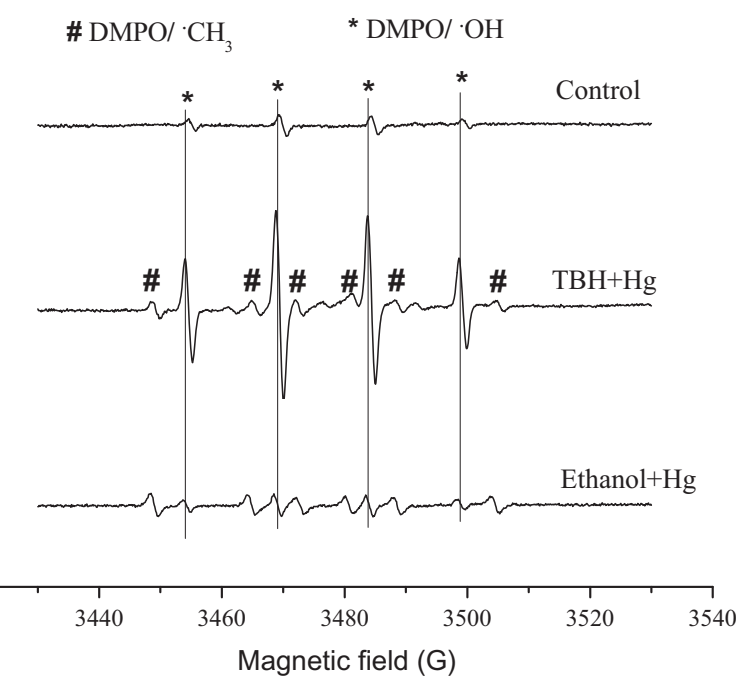

Fig. 6. EPR spectrum of methyl and hydroxyl radicals in the reaction solutions containing $\mathrm{Hg}$ and $\mathrm{TBH}$ or ethanol under UV irradiation. The experiments were conducted in solutions containing $1 \mu \mathrm{g} \mathrm{mL}^{-1}$ (as $\mathrm{Hg}$ ) of $\mathrm{HgCl}_{2}, 1 \% \mathrm{NaCl}(\mathrm{w} / \mathrm{v}), 0.1 \mathrm{M}$ methyl donors, and $50 \mathrm{mM}$ of the spin-trapping agent 5,5-dimethyl-1-pyrroline $\mathrm{N}$ oxide (DMPO). The control denotes the solution only containing Hg and DMPO. 


\subsection{Mechanism of photochemical methylation of $\mathrm{Hg}$}

The exact mechanism responsible for the photo-methylation of $\mathrm{Hg}$ by LMWOCs remains a matter of debate (Akagi et al., 1974; Hayashi et al., 1977). The formation of $\mathrm{Hg}^{2+}$-LMWOC complexes is considered a key step preceding $\mathrm{Hg}$ photo-methylation in aqueous solution under UV irradiation (Akagi et al., 1974; Yin et al., 2012). The absorbance of TBA in the UV-visible spectrum was scanned using a Hitachi U-3310 spectrophotometer (Fig. 5A). The results demonstrated clear increase in the absorbance intensities of TBA and a shift of their light absorbance wavelength to the red region after the addition of $\mathrm{Hg}^{2+}$, which supported the formation of complexes of $\mathrm{Hg}^{2+}$ and TBA. In fact, $\mathrm{Hg}^{2+}$, as a strong Lewis acid, can complex with Lewis bases, for example, ketone and organic acid (Gardfeldt et al., 2003; King et al., 2002; Yin et al., 2012). Moreover, the low $\mathrm{MeHg}$ yield under irradiation of visible light or sunlight can be explained by the weak absorbance of methyl donors of visible light.

Methyl radical ( $\left.{ }^{\circ} \mathrm{CH}_{3}\right)$ and $\cdot \mathrm{OH}$ were also determined using the EPR technique, with DMPO as a trapping agent of free radicals. This experiment can further illustrate whether $\mathrm{MeHg}$ is generated via a transfer of free methyl radicals from methyl donors to $\mathrm{Hg}$. $\mathrm{TBH}$ and ethanol were selected as the model compounds for EPR analysis because of the maximal difference in their respective MeHg yields. Fig. 6 shows the EPR spectrum of methyl and hydroxyl radicals in the reaction solutions containing $\mathrm{Hg}$ and $\mathrm{TBH}$ or ethanol under UV irradiation. The results demonstrated that both TBH and ethanol could produce ${ }^{\circ} \mathrm{CH}_{3}$ and $\mathrm{OH}$ in aqueous solution under UV irradiation. However, the difference in the concentration of $\mathrm{CH}_{3}$ between TBH and ethanol was not consistently negligible as their respective MeHg yields varied greatly (Fig. 6). Therefore, the direct transfer of free methyl radical to $\mathrm{Hg}$ was not considered to be chiefly responsible for the photo-methylation of $\mathrm{Hg}$ by LMWOCs in aqueous solution under UV irradiation (Yin et al., 2012).

Fig. 7A shows a tentative mechanism for the photo-methylation of $\mathrm{Hg}^{2+}$ by TBA and TBH in aqueous solution under UV irradiation. The complexes of $\mathrm{Hg}^{2+}$ and TBA or TBH could form an intermediate $\left(\mathrm{O}(\mathrm{Hg}) \mathrm{C}\left(\mathrm{CH}_{3}\right)_{3}\right)$ in the aqueous solution under UV irradiation. MeHg was produced from $\left(\cdot \mathrm{O}(\mathrm{Hg}) \mathrm{C}\left(\mathrm{CH}_{3}\right)_{3}\right)$ via an intramolecular transfer of the methyl group. The formation of $\cdot \mathrm{O}(\mathrm{Hg}) \mathrm{C}\left(\mathrm{CH}_{3}\right)_{3}$ was a key step in the photo-production of $\mathrm{MeHg}$ under UV irradiation.

(A)<smiles>CC(C)(C)O[14CH2][14CH2][14C](C)(C)C</smiles>

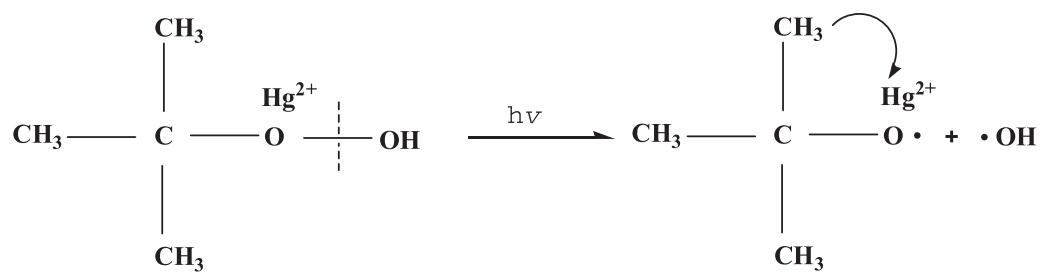

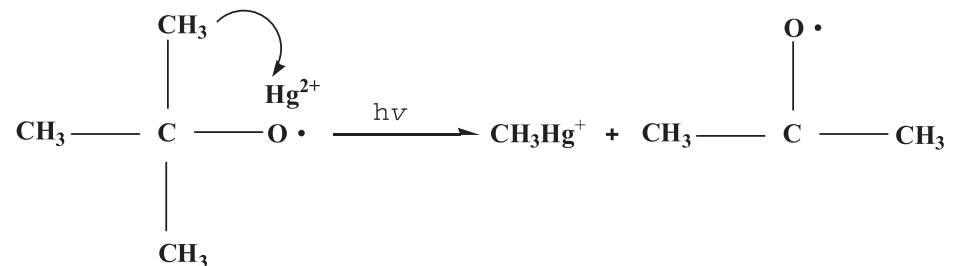

(B)

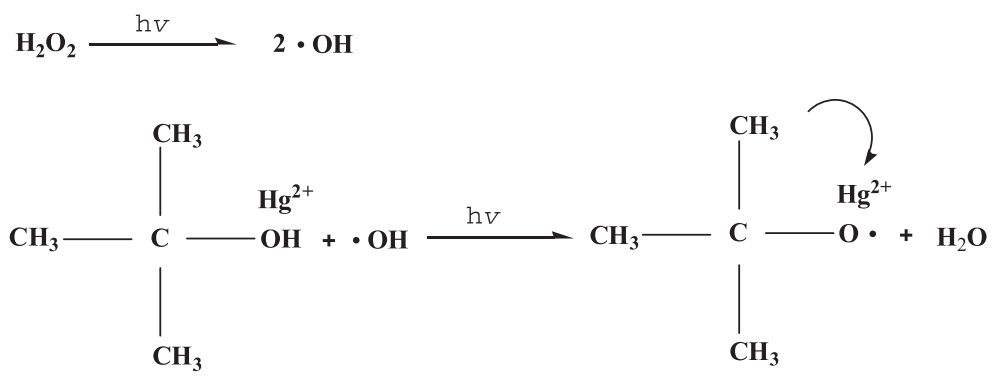

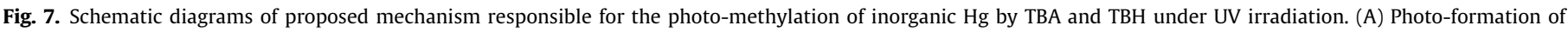
$\mathrm{MeHg}$; (B) the effect of $\mathrm{OH}$ on the photo-formation of $\mathrm{MeHg}$. 
The bond energy of O-O in TBH is much lower than that of $\mathrm{O}-\mathrm{H}$ in TBA. Consequently, the weaker bond energy of TBH facilitated the formation of $\mathrm{O}(\mathrm{Hg}) \mathrm{C}\left(\mathrm{CH}_{3}\right)_{3}$, and in turn a higher yield, in comparison with TBA. Moreover, the low level of $\mathrm{OH}$ could be produced by the photolysis of $\mathrm{H}_{2} \mathrm{O}_{2}$ under UV irradiation, which considerably promoted the generation of $\mathrm{O}(\mathrm{Hg}) \mathrm{C}\left(\mathrm{CH}_{3}\right)_{3}$ and in turn the production of $\mathrm{MeHg}$ (Fig. 7B). Thus, the formation of ${ }^{\circ} \mathrm{OH}$ was also considered to be an important factor influencing the photo-methylation of elements.

\section{Conclusion}

MeHg can be produced in the presence of TBH under visible light irradiation. The photoreactions of inorganic $\mathrm{Hg}$ and LMWOCs potentially contributed to the production of $\mathrm{MeHg}$ in aquatic environments. Interestingly, a low level of ' $\mathrm{OH}$ could promote the photo-methylation of $\mathrm{Hg}$, via capture by organic methyl donors, whereas excess $\mathrm{OH}$ could lead to the degradation of $\mathrm{MeHg}$. Photoreactions between $\mathrm{Hg}$ and organic pollutants are important in understanding the fate and transformation of $\mathrm{Hg}$ in the environment.

\section{Acknowledgments}

This work was jointly supported by the National Natural Science Foundation of China (21307167, 40903046, 41202136, 41271505, and 20937002), the National Basic Research Program of China (2013CB430004), and the Doctoral Fund of Ministry of Education of China (20130171120038).

\section{References}

Akagi, H., Fujita, Y., Takabatake, E., 1974. Photochemical methylation of inorganic mercuric compounds in aqueous acetic acid solutions. J. Jpn. Chem. Soc. 7 $1180-1184$.

Ayotte, J.D., Argue, D.M., Mcgarry, F.J., Degnan, J.R., Hayes, L., Flanagan, S.M., Helsel D.R. 2008. Methyl tert-butyl ether (MTBE) in public and private wells in new hampshire: Occurrence, factors, and possible implications. Environ. Sci. Technol. 42, 677-684.

Bridou, R., Monperrus, M., Gonzalez, P.R., Guyoneaud, R., Amouroux, D., 2011 Simultaneous determination of mercury methylation and demethylation capacities of various sulfate-reducing bacteria using species-specific isotopic tracers. Environ. Toxicol. Chem. 30, 337-344.

Cederbaum, A.I., Qureshi, A., Cohen, G., 1983a. Production of formaldehyde and acetone by hydroxyl-radical generating systems during the metabolism of tertiary butyl alcohol. Biochem. Pharmacol. 32, 3517-3524.

Cederbaum, A.I., Qureshi, A., Cohen, G., 1983b. Production of formaldehyde and acetone by hydroxyl-radical generating systems during the metabolism of tertiary butyl alcohol. Biochem. Pharmacol. 32, 3517-3524.

Celo, V., Lean, D.R.S., Scott, S.L., 2006. Abiotic methylation of mercury in the aquatic environment. Sci. Total Environ. 368, 126-137.

Cerrati, G., Bernhard, M., Weber, J.H., 1992. Model reactions for abiotic mercury(Ii) methylation - kinetics of methylation of mercury(Ii) by mono-methyltin, dimethyltin, and tri-methyltin in seawater. Appl. Organomet. Chem. 6, 587-595.

Chen, J., Pehkonen, S.O., Lin, C.J., 2003. Degradation of monomethylmercury chloride by hydroxyl radicals in simulated natural waters. Water Res. 37, 2496-2504.

Chen, B.W., Wang, T., He, B., Yuan, C.G., Gao, E.L., Jiang, G.B., 2006. Simulate methylation reaction of arsenic(III) with methyl iodide in an aquatic system. Appl. Organomet. Chem. 20, 747-753.

Chen, B.W., Wang, T., Yin, Y.G., He, B., Jiang, G.B., 2007a. Methylation of inorganic mercury by methylcobalamin in aquatic systems. Appl. Organomet. Chem. 21 $462-467$.

Chen, B.W., Zhou, Q.F., Liu, J.Y., Cao, D.D., Wang, T., Jiang, G.B., 2007b. Methylation mechanism of tin(II) by methylcobalamin in aquatic systems. Chemosphere 68 414-419.

Chen, B.W., Wang, T., Yin, Y.G., He, B., Jiang, G.B., 2012. Identification of photochemical methylation products of tin(II) in aqueous solutions using headspace SPME coupled with GC-FPD or GC-MS. Anal. Method.-Uk 4, 2109 2114.

Conaway, C.H., Black, F.J., Weiss-Penzias, P., Gault-Ringold, M., Flegal, A.R., 2010. Mercury speciation in Pacific coastal rainwater, Monterey Bay, California. Atmos. Environ. 44, 1788-1797.

Crespo-Lopez, M.E., Herculano, A.M., Corvelo, T.C., Do Nascimento, J.L., 2005 Mercury and neurotoxicity. Rev. Neurol. 40, 441-447.

Darbieu, M.H., 1993. The Toxicity of Methylmercury. Rev. Roum. Chim. 38, 107-114.
Diez, S., 2009. Human health effects of methylmercury exposure. Rev. Environ. Contam. Toxicol. 198, 111-132.

Fleming, E.J., Mack, E.E., Green, P.G., Nelson, D.C., 2006. Mercury methylation from unexpected sources: Molybdate-inhibited freshwater sediments and an ironreducing bacterium. Appl. Environ. Microb. 72, 457-464.

Gardfeldt, K., Munthe, J., Stromberg, D., Lindqvist, O., 2003. A kinetic study on the abiotic methylation of divalent mercury in the aqueous phase. Sci. Total Environ. 304, 127-136.

Grandjean, P., 2007. Methylmercury toxicity and functional programming. Reprod. Toxicol. 23, 414-420.

Guo, X.M., Sturgeon, R.E., Mester, Z., Gardener, G.K., 2003. Photochemical alkylation of inorganic selenium in the presence of low molecular weight organic acids. Environ. Sci. Technol. 37, 5645-5650.

Guo, X.M., Sturgeon, R.E., Mester, Z., Gardner, G.J., 2005. Photochemical alkylation of inorganic arsenic - Part 1. Identification of volatile arsenic species. J. Anal. Atom. Spectrom. 20, 702-708.

Hall, B.D., Baron, L.A., Somers, C.M., 2009. Mercury concentrations in surface water and harvested waterfowl from the prairie pothole region of Saskatchewan. Environ. Sci. Technol. 43, 8759-8766.

Hamilton, J.T.G., McRoberts, W.C., Keppler, F., Kalin, R.M., Harper, D.B., 2003. Chloride methylation by plant pectin: An efficient environmentally significant process. Science 301, 206-209.

Hammerschmidt, C.R., Lamborg, C.H., Fitzgerald, W.F., 2007. Aqueous phase methylation as a potential source of methylmercury in wet deposition. Atmos. Environ. 41, 1663-1668.

Hayashi, K., Kawai, S., Ohno, T., Maki, Y., 1977. Photomethylation of inorganic mercury by aliphatic alpha-amino-acids. J. Chem. Soc. Chem. Comm., 158-159

He, B., Gao, E., Shi, J.B., Liang, L.N., Yin, Y.G., Jiang, G.B., 2006. Optimization of pretreatment method for alkylmercuries speciation in coal by highperformance liquid chromatography coupled with UV-digestion cold vapor atomic fluorescence spectrometry. Spectrosc. Lett. 39, 785-796.

Hwang, S., Huling, S.G., Ko, S., 2010. Fenton-like degradation of MTBE: Effects of iron counter anion and radical scavengers. Chemosphere 78, 563-568.

Jensen, S., Jernelov, A., 1969. Biological methylation of mercury in aquatic organisms. Nature 223, 753-754.

Jonsson, S., Skyllberg, U., Nilsson, M.B., Westlund, P.O., Shchukarev, A., Lundberg, E., Bjorn, E., 2012. Mercury methylation rates for geochemically relevant $\mathrm{Hg}$ (II) species in sediments. Environ. Sci. Technol. 46, 11653-11659.

Kieber, R.J., Parler, N.E., Skrabal, S.A., Willey, J.D., 2008. Speciation and photochemistry of mercury in rainwater. J. Atmos. Chem. 60, 153-168.

King, J.B., Tsunoda, M., Gabbai, F.P., 2002. Complexation of aldehydes and ketones by trimeric perfluoro-ortho-phenylene mercury, a tridentate Lewis acid. Organometallics 21, 4201-4205.

Lehnherr, I., Louis, V.L.S., 2009. Importance of ultraviolet radiation in the photodemethylation of methylmercury in freshwater ecosystems. Environ. Sci. Technol. 43, 5692-5698.

Li, Y.B., Mao, Y.X., Liu, G.L., Tachiev, G., Roelant, D., Feng, X.B., Cai, Y, 2010. Degradation of methylmercury and its effects on mercury distribution and cycling in the Florida Everglades. Environ. Sci. Technol. 44, 6661-6666.

Li, Y., Zhu, T., Zhao, J., Xu, B., 2012. Interactive enhancements of ascorbic acid and iron in hydroxyl radical generation in quinone redox cycling. Environ. Sci. Technol. 46, 10302-10309.

Liu, H., Zhao, H.M., Quan, X., Zhang, Y.B., Chen, S., 2009. Formation of chlorinated intermediate from bisphenol A in surface saline water under simulated solar light irradiation. Environ. Sci. Technol. 43, 7712-7717.

McSheehy, S., Guo, X.M., Sturgeon, R.E., Mester, Z., 2005. Photochemical alkylation of inorganic arsenic - Part 2. Identification of aqueous phase organoarsenic species using multidimensional liquid chromatography and electrospray mass spectrometry. J. Anal. Atom. Spectrom. 20, 709-716.

Moore, R.M., 2008. A photochemical source of methyl chloride in saline waters. Environ. Sci. Technol. 42, 1933-1937.

Muir, D.C., Wang, X., Yang, F., Nguyen, N., Jackson, T.A., Evans, M.S., Douglas, M., Kock, G., Lamoureux, S., Pienitz, R., Smol, J.P., Vincent, W.F., Dastoor, A., 2009. Spatial trends and historical deposition of mercury in eastern and northern Canada inferred from lake sediment cores. Environ. Sci. Technol. 43, 4802-4809.

Obrist, D., Johnson, D.W., Lindberg, S.E., Luo, Y., Hararuk, O., Bracho, R., Battles, J.J., Dail, D.B., Edmonds, R.L., Monson, R.K., Ollinger, S.V., Pallardy, S.G., Pregitzer, K.S., Todd, D.E., 2011. Mercury distribution across 14 U.S. Forests. Part I: spatial patterns of concentrations in biomass, litter, and soils. Environ. Sci. Technol. 45, 3974-3981.

Parks, J.M., Johs, A., Podar, M., Bridou, R., Hurt Jr., R.A., Smith, S.D., Tomanicek, S.J. Qian, Y., Brown, S.D., Brandt, C.C., Palumbo, A.V., Smith, J.C., Wall, J.D., Elias, D.A., Liang, L., 2013. The genetic basis for bacterial mercury methylation. Science $339,1332-1335$.

Rosell, M., Lacorte, S., Ginebreda, A., Barcelo, D., 2003. Simultaneous determination of methyl tert.-butyl ether and its degradation products, other gasoline oxygenates and benzene, toluene, ethylbenzene and xylenes in Catalonian groundwater by purge-and-trap-gas chromatography-mass spectrometry. J. Chromatogr. A 995, 171-184.

Schmidt, T.C., Schirmer, M., Weiss, H., Haderlein, S.B., 2004. Microbial degradation of methyl tert-butyl ether and tert-butyl alcohol in the subsurface. J. Contam. Hydrol. 70, 173-203.

Siciliano, S.D., O’Driscoll, N.J., Tordon, R., Hill, J., Beauchamp, S., Lean, D.R., 2005. Abiotic production of methylmercury by solar radiation. Environ. Sci. Technol. 39, 1071-1077. 
van Vliet, E., Morath, S., Eskes, C., Linge, J., Rappsilber, J., Honegger, P., Hartung, T., Coecke, S., 2008. A novel in vitro metabolomics approach for neurotoxicity testing, proof of principle for methyl mercury chloride and caffeine. Neurotoxicology 29, 1-12.

Vonpiechowski, M., Thelen, M.A., Hoigne, J., Buhler, R.E., 1992. Tert-butanol as an oh-scavenger in the pulse-radiolysis of oxygenated aqueous systems. Ber. Bunsen. Phys. Chem. 96, 1448-1454.

Weber, J.H., Reisinger, K., Stoeppler, M., 1985. Methylation of mercury(Ii) by fulvicacid. Environ. Technol. Lett. 6, 203-208.

Williams, P.R.D., Pierce, J.S., 2009. Overview of Methyl Tertiary Butyl Ether (MTBE) detections in public drinking water supplies in the United States. Environ. Forensics 10, 33-50.
Yin, Y.G., Liu, J.F., He, B., Shi, J.B., Jiang, G.B., 2008. Simple interface of highperformance liquid chromatography-atomic fluorescence spectrometry hyphenated system for speciation of mercury based on photo-induced chemical vapour generation with formic acid in mobile phase as reaction reagent. J. Chromatogr. A 1181, 77-82.

Yin, Y.G., Chen, B.W., Mao, Y.X., Wang, T., Liu, J.F., Cai, Y., Jiang, G.B., 2012. Possible alkylation of inorganic $\mathrm{Hg}$ (II) by photochemical processes in the environment Chemosphere 88, 8-16.

Zhang, Z., Wang, Q., Zheng, D., Zheng, N., Lu, X., 2010. Mercury distribution and bioaccumulation up the soil-plant-grasshopper-spider food chain in Huludao City, China. J. Environ. Sci. (China) 22, 1179-1183. 